\title{
Hereditary prosopagnosia (HPA): the first report outside the Caucasian population
}

\author{
Ingo Kennerknecht $\cdot$ Nina Plümpe $\cdot$ Steve Edwards • \\ Rajiva Raman
}

Received: 31 August 2006/ Accepted: 6 December 2006/Published online: 22 December 2006

(C) The Japan Society of Human Genetics and Springer 2006

\begin{abstract}
Prosopagnosia (PA) or face blindness is characterized by a deficiency in identifying familiar faces. Almost all reports are single cases or collections of unrelated patients who acquired prosopagnosia after brain injuries, strokes or atrophy of at least the right occipito-temporal cortex. Until 2001, the inborn for$\mathrm{m}$-in the absence of any brain lesions-was described in fewer than 20 probands exclusively of Caucasian origin. We recently found that in the German Caucasian population, congenital prosopagnosia has a very high prevalence of at least $2.5 \%$ and that it is genetically determined. It is best described by autosomaldominant inheritance in the more than 50 families investigated. We therefore introduced the term nonsyndromic hereditary PA for the congenital form of a monosymptomatic or isolated PA. This surprisingly high frequency in the Caucasian population prompted us to extend our search to other ethnic groups. We performed a questionnaire-based screening among 198 native Indian students at Banaras Hindu University in Varanasi. In a then selected subset, we found after further detailed diagnostic interviews one Bengali
\end{abstract}

I. Kennerknecht $(\bowtie) \cdot$ N. Plümpe

Institut für Humangenetik,

Westfälische Wilhelms Universität,

Münster, Germany

e-mail: kennerk@uni-muenster.de

S. Edwards

Department of Psychology, Zululand University,

P. Bag X1001, KwaDlangezwa 3886, South Africa

R. Raman

Department of Zoology and Molecular and Human

Genetics, Banaras Hindu University,

Varanasi 221005, India female student with visual agnosia for face recognition only. Several other members of her large family reported the same impairment of face recognition. The segregation pattern of PA in this family is also compatible with autosomal-dominant inheritance.

Keywords Congenital prosopagnosia $\cdot$ Hereditary prosopagnosia . Face blind P Prevalence - Caucasian population $\cdot$ Indian population

\section{Introduction}

Prosopagnosia, a term first introduced by Bodamer (1947), is defined as the inability to recognize faces of individuals, while faces as such and facial expressions can be recognized. The most familiar faces, even their own faces, can be puzzling. The specificity of this deficiency is best supported by double dissociation between probands with impairments such as object agnosia, but not prosopagnosia and vice versa. Almost all reports are of single cases or collections of unrelated patients who acquired PA after brain injuries, strokes or atrophy, including the right occipito-temporal cortex. There are only a few reports of congenital, developmental or childhood PA (Ariel and Sadeh 1996; Behrmann and Avidan 2005; Bentin et al. 1999; De Gelder and Rouw 2000; Duchaine 2000; Duchaine et al. 2003; De Haan 1999; De Haan and Campbell 1991; Hasson et al. 2003; Jones and Tranel 2001; Kress and Daum 2003; McConachie 1976; Nunn et al. 2001; Temple 1992). The terms congenital, developmental, childhood and acquired are sometimes loosely used without taking into account the (putative) etiology. The first hints of familial recurrence were given by 
McConachie (1976), de Haan (1999) and Galaburda and Duchaine (2003). However, the familial segregation pattern was not studied in anymore detail. Recently, we could show in all 38 German families studied that the segregation pattern of congenital prosopagnosia is fully compatible with an autosomal-dominant mode of inheritance (Grueter et al. 2007). We could further show that the inborn form-in the absence of any traumatic event-is very common, with a minimal prevalence of $2.5 \%$ (Kennerknecht et al. 2006). And again, of the 17 cases of the disorder, all 14 subjects who consented to further intrafamilial testing had at least one first-degree prosopagnosic relative; this finding is compatible with an autosomal-dominant mode of inheritance. This congenital monosymptomatic Mendelian cognitive deficit might be best described as "non-syndromic hereditary PA (HPA)." It is one of the most common and also most often overlooked monogenic disorders. Up to date, all cases of inborn prosopagnosia have been reported exclusively in the Caucasian population. Based on the very high prevalence in the German population-consisting of a large variety of Caucasian ethnicities-HPA should also be present in other ethnic groups.

\section{Materials and methods}

This study was carried out with ethical committee approval from the University of Münster, Germany, protocol no. 3XKenn2, "Genotype/phenotype correlation of prosopagnosia (syn. face blindness)." After informed consent, we asked all the native Indian students in seminars of several faculties of the Banaras Hindu University to fill in a four-page questionnaire. Only after having filled in the questionnaire were the students given detailed information on the project. A diagnostic semi-structured interview was requested from all persons highly suspicious for prosopagnosia.

\section{Screening tools}

The screening and diagnostic procedure followed a recently evaluated procedure in a cohort of German secondary school pupils and first year medical students (Kennerknecht et al. 2006). A four-page questionnaire concentrated on anamnestic data, excluding any event of brain lesion (perinatal asphyxia, epileptic attack, meningitis, brain injuries or brain surgery). We asked in detail for other object agnosias (especially for intraclass object recognition of houses, money bags, mobiles, birds, trees, etc.) as well as for mental images of non-facial and facial objects, and for concomitant visual agnosias.

Secondly, in order to facilitate the questionnairebased screening in respect to successive studies, we reduced the number of questions to 15 and assessed responses on a five-point rating scale. This was also distributed among a distinct group of normal and prosopagnosic native Indian and native German students, respectively. The test items are listed in Table 2. The scoring stencil was set to " 5 " in favor of prosopagnosia and to " 1 " for controls. Four questions (nos. 10-13) were included as distracters as they are known to be commonly unimpaired in prosopagnosics.

\section{Diagnostic assessment}

As the questionnaire does not allow unambiguous assessment and diagnosis of prosopagnosia, it could serve only as a screening tool for persons highly suspicious of prosopagnosia. The then selected probands were interviewed in detail to establish the diagnosis as has been described recently (Kennerknecht et al. 2006). In short, the diagnostic approach to hereditary prosopagnosics consisted of: (1) anamnestic data excluding any event of brain lesion or neurological or psychiatric disorders, (2) a semi-structured interview concentrating on cognitive features and (3) detailed data about the family history concentrating on recurrent PA.

The diagnosis itself is based on qualitative differences. Basically, we relied on the delineation of secondary behavioral adaptations such as compensation (e.g., the pupils of a prosopagnosic teacher always have to sit in the same place in the classroom), explanation (e.g., "Sorry, I have forgotten my glasses") and avoidance strategies (e.g., not going to huge gatherings with only a few known people who will expect in any case to be recognized). Also, anecdotal stories of events such as having overlooked familiar people are extremely helpful.

\section{Results}

After 198 native Indian students (69 males and 129 females) filled in the four-page questionnaire, 28 (6 males and 22 females) were suspicious for prosopagnosia. Eleven students agreed to be interviewed in depth (two males and nine females). We identified one prosopagnosic female student originating from Calcutta. After having filled in the questionnaire and read our short handout on prosopagnosia, she described herself as having this impairment (Table 1). 
Table 1 Questionnaire-based screening for prosopagnosia among native Indian students

\begin{tabular}{|c|c|c|c|c|c|c|c|c|c|c|c|}
\hline \multicolumn{3}{|c|}{ Questionnaires completed } & \multicolumn{3}{|c|}{$\begin{array}{l}\text { Highly suspicious for } \\
\text { prosopagnosia according to } \\
\text { questionnaire-based screening }\end{array}$} & \multicolumn{3}{|c|}{$\begin{array}{l}\text { Subjects agreeing to an } \\
\text { in-depth interview }\end{array}$} & \multicolumn{3}{|c|}{$\begin{array}{l}\text { Diagnosis of prosopagnosia } \\
\text { established by the interview } \\
\text { (for test items, see Table 2) }\end{array}$} \\
\hline $\begin{array}{l}\text { Male } \\
(N)\end{array}$ & $\begin{array}{l}\text { Female } \\
(N)\end{array}$ & $\begin{array}{l}\text { Total } \\
(N)\end{array}$ & $\begin{array}{l}\text { Male } \\
(N)\end{array}$ & $\begin{array}{l}\text { Female } \\
(N)\end{array}$ & $\begin{array}{l}\text { Total } \\
(N)\end{array}$ & $\begin{array}{l}\text { Male } \\
(N)\end{array}$ & $\begin{array}{l}\text { Female } \\
(N)\end{array}$ & $\begin{array}{l}\text { Total } \\
(N)\end{array}$ & $\begin{array}{l}\text { Male } \\
(N)\end{array}$ & $\begin{array}{l}\text { Female } \\
(N)\end{array}$ & $\begin{array}{l}\text { Total } \\
(N)\end{array}$ \\
\hline 69 & 129 & 189 & 6 & 22 & 28 & 2 & 9 & 11 & 0 & 1 & 1 \\
\hline
\end{tabular}

Proband's history

After an uneventful pregnancy, she was delivered at term by section cesarea indicated by decelerations. There were no remarkable traumatic events or infectious diseases of the head. She had long been aware of having problems in face recognition. She identified her parents, younger brother and sister by their hair cuts, glasses and teeth, and sometimes the way they smiled. She preferred to go to parties with a group who could support her. She had problems following actors in a movie. In Indian movies, she concentrated on the different saris. However, when they changed clothing, she got lost. The same was true for American films when the actors wore similar black suits. If an actor was very characteristic, like Arnold Schwarzenegger, she could follow him throughout the film by his broad shoulders and his muscular body. However, in another movie when he appeared unexpectedly, she did not recognize him. She also overlooked the famous Indian actor Amitabh Bachan when she came across him unexpectedly in a temple. On the other hand, she recognized a young man at Varanasi railway station whom she had spoken to 4 weeks before in Delhi. She could remember him by his bright red shirt and the glasses he was wearing. She was often criticized for not greeting her friends. In short, hair cuts, glasses, teeth and clothing were her main identifiers.

For her, the face itself was not informative for recognizing people. She used eye contact just to be sure whether the people were still interested in her and to read their facial emotions. The feeling for attractiveness is obviously the same as for her classmates. She had no or very blurred inner images of her parents or close friends, as was also true for objects. For example, during meditation she could not visualize a waterfall. However, object recognition in general was not disturbed and clearly dissociated from her impaired face recognition. She especially had no problems recognizing individual members of a particular class of objects, e.g., in identifying a peculiar pair of scissors among others. She was also well orientated.

A neurological exam indicated normal clinical status. There were no hints of any delusional symptoms, psychiatric disorders or autism spectrum disorders. Such disorders would not have allowed her to become a member of a master class of 20 selected students out of 2,000 applicants. She is socially well integrated.

\section{Family history}

The family of the index subject could not be studied in full detail as the contact stopped when leaving the university. So far, there is ample evidence that the mother has the same face recognition deficit, as is the case in one maternal aunt and their son. The father is unimpaired. However, in his family two brothers are most probably prosopagnosics. One brother has a daughter, the other a son and grandson with the same dysfunction (Fig. 1).

\section{One-page questionnaire}

The short screening questionnaire indicated a score of 51 for the Indian prosopagnosic student, with a mean Indian control group score of 28.29 and standard deviation of 6.16 and a mean German control group score of 26.32 and standard deviation of 5.50. Among German prosopagnosic students, we have a mean score of 47.7 and a standard deviation of 5.99. Hence, prosopagnosics are around three standard deviations above the mean (Table 2). Three standard deviations above the mean exclude some $99.73 \%$ of a normally distributed sample and indicate an acceptable clinical, statistical cutoff point for the preliminary identification of individual prosopagnosics at this early research stage. Obviously full, qualitative diagnostic evaluation is needed to confirm such a preliminary quantitative identification. It is clear that around five questions out of those with a resulting mean score of $>3.5$ in prosopagnosics and $<2.0$ in controls will already allow an easy screening.

\section{Discussion}

Prosopagnosia or the inability to recognize people by their face alone, is thought to be rare. Nearly all re- 


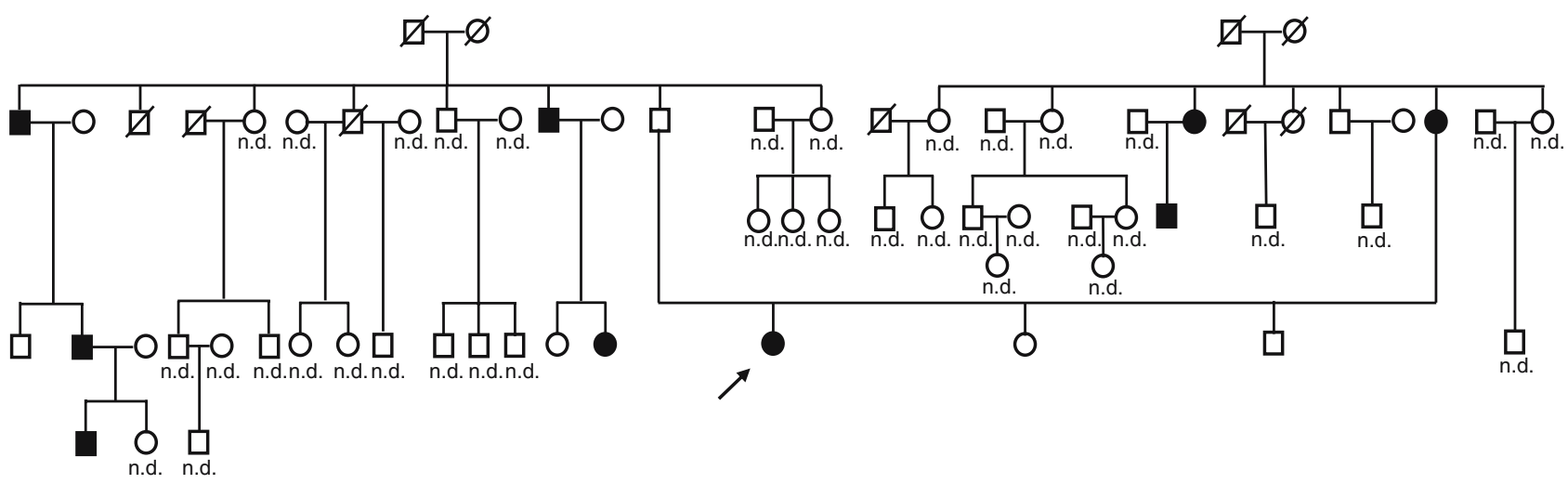

Fig. 1 Pedigree of our Indian student. Arrow indicates the index subject, filled symbols prosopagnosics and n.d. not determined. Her mother, a maternal aunt and their son are also prosopagnosics. Interestingly, in the family of her father, who himself is unimpaired, segregation of prosopagnosia also has been observed in three generations, including both sexes and repeated father-toson transmissions, being compatible with simple autosomal-

ports describe the acquired form after head injuries or stroke. These cases are easy to identify by the sudden loss of the ability to tell individuals apart by facial cues. The inborn form is almost always overlooked as PA can be compensated quite well in daily life. Both forms are thought to be rare, especially the congenital form. However, we could recently show that the latter form is very common with a minimal prevalence of $2.5 \%$ in the Caucasian population (Kennerknecht et al. 2006). Hence, PA should also be common at least in proximal ethnic groups belonging to the Indo-German language group.

A prerequisite and crucial point is the establishing of the diagnosis. No common procedure has been published. In an initial study, we did attempt to assess the diagnoses more objectively (Grueter et al. 2007). Eight out of 38 hereditary prosopagnosics from seven families agreed with in-depth testing. The Warrington Recognition Memory Test for Faces, RMF (Warrington 1984), famous and family faces tests, learning tests for internal and external facial features and a measure of mental imagery for face and non-face images were conducted on these eight hereditary prosopagnosics. The results of all these tests were fully compatible with the data of the individual interviews, as was true with respective familial segregation data. All congenital prosopagnosics report that throughout their entire life they have been unable to recognize people by their faces alone. They report that context enables them to recognize others more easily and that they identify people by their hair, voice, gait, etc. Furthermore, they reported that they sometimes do not even recognize very close relatives and that they avoid participating in dominant inheritance. Regarding the high frequency of prosopagnosia-at least in the Caucasian population-this finding might be rather coincidental. However, as long as molecular genetic data are not available, it remains unclear whether the father is a normal transmitter-indicating a reduced penetrance of prosopagnosia-and whether our index subject might be homozygous or compound heterozygous for prosopagnosia

large events where they cannot be sure who they will meet. They are not impaired in general pattern recognition, e.g., in the affected and non-affected members of one family we can see a clear double dissociation of impaired face recognition and orientation in a city. We also know a prosopagnosic physician who did histological staging of cancer tissues and who later worked as a radiologist.

From the pool of prosopagnosics described above, two further studies were initiated. Four subjects underwent eye tracking studies. It could be shown that their visual cognitive deficit is reflected in their gaze behavior. The prosopagnosics had a more dispersed gaze and also fixated more external facial features (Schwarzer et al. 2006). Another three subjects were studied by standardized test batteries, tailor-made experimental paradigms and clinical questionnaires. These were part of a total collection of six prosopagnosics examined by Dobel et al. (2007). As compared to controls, all six subjects showed deficits in recognizing famous faces and retaining novel faces over short periods of time, whereas other aspects of face perception, e.g., emotional expression, were unimpaired.

As these time-consuming tools are not suitable for population-based screening, a four-page questionnaire, which had been tested successfully in a German cohort (Kennerknecht et al. 2006), was also applied in an English version for Indian students. In addition, we could show in this study that screening based only on a few selected questions easily identifies subjects highly suspicious for prosopagnosia. The Indian student, we found, showed an almost similar profile to our German 


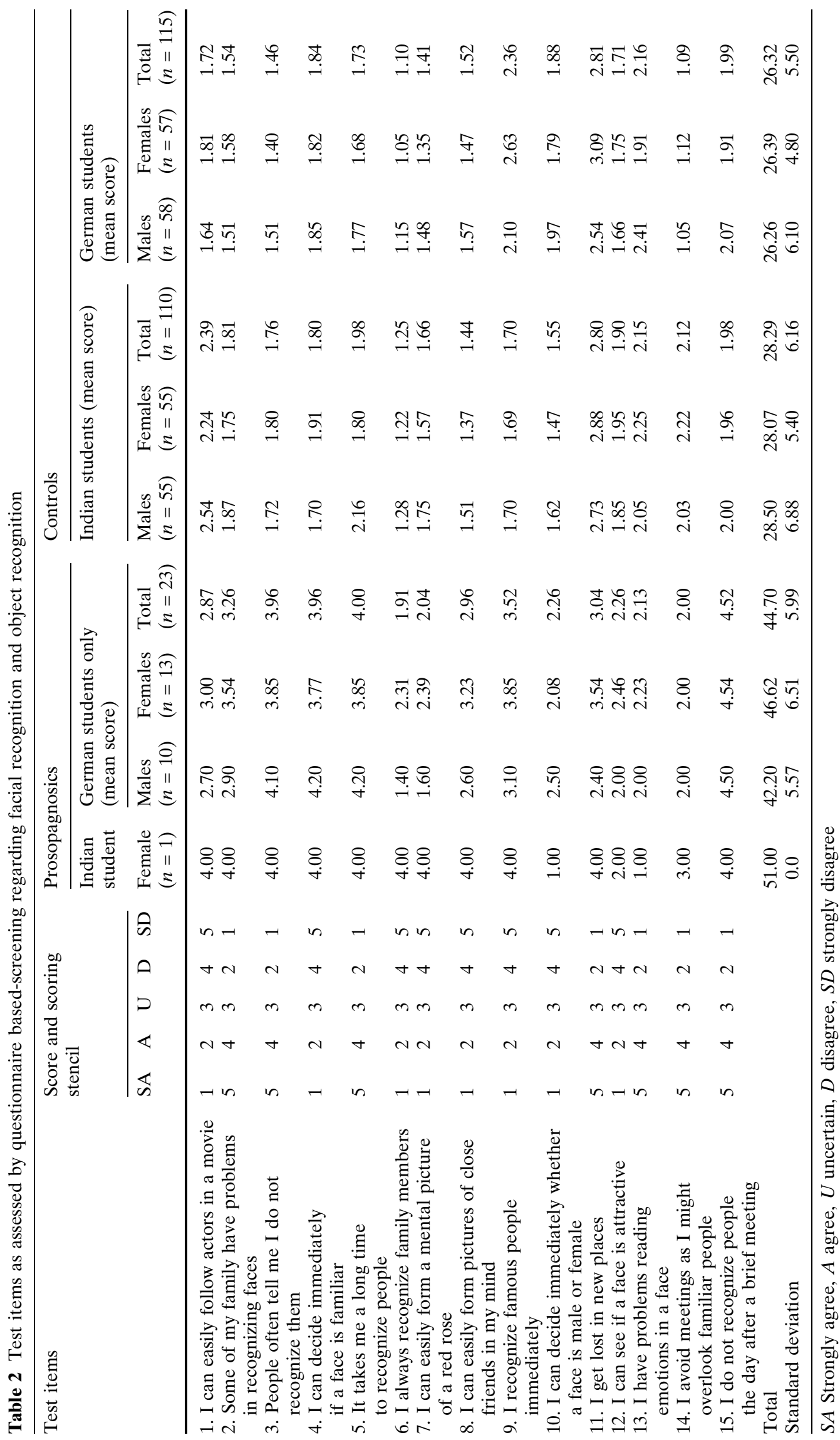


targets, clearly showing that this dysfunction is unique and relatively independent of cultural and ethnic background. Although we did not have the opportunity to study her family in any detail, there is ample evidence for familial recurrence, and most interestingly also in favor of an autosomal-dominant mode of inheritance. Also in the family of her father, who himself is unimpaired, recurrent prosopagnosia occurs in three generations. This is most probably a coincidental finding that seems to be-against the background of the very high prevalence-not uncommon. We have observed a similar pattern in two German families (Grueter 2004; Grueter et al. 2007). However, as long as molecular genetic data are not available, it cannot be definitely excluded that some of them might be normal transmitters. Among 60 families that we have studied so far, we have no clear formal genetic evidence for a reduced penetrance. However, regarding the high frequency of prosopagnosia, homozygous carriers or in case of genetic heterogeneity compound heterozygous carriers should exist. In these cases, a putative differential influence on the phenotypic expression is certainly of high interest.

Research is in progress to establish international, cross-cultural means, standard deviations and acceptable cutoff points to establish a preliminary diagnosis on the basis of the quantitative screening questionnaire. While it needs refining, the instrument has demonstrated its usefulness as a screening tool in this study. As indicated in Table 2, the identified prosopagnosics score of 51 is clearly well above the mean score of 28.29 for the Indian control population and in the range of the mean score of 44.7 obtained for other prosopagnosic Germans.

The genetic histories of contemporary populations in India are under study by a variety of groups using autosomal, Y-chromosomal and mitochondrial markers. Our student is ethnically a Bengali and hence a speaker of an Indo-Aryan dialect. This might distinguish her from Dravidian populations and point to an Indo-European influence, rather than an Austro-Asiatic. India is made up of a huge pool of genetically diverse populations, which indicates no single origin, In this chapter only the peopling of India is discussed and not the putative origin of a disorder (e.g., PA) but a conglomeration of different lineages (Qintana-Murci et al 2001; Bamshad et al. 2003; Basu et al. 2003; Kivisild et al. 2003; Kumar and Reddy 2003; Saha et al. 2005). Once having cloned the gene(s), mutation analyses might document whether there is (1) a (very old) founder mutation, whether there are (2) "private" mutations pointing to a high rate of new mutations or whether there is a (3) genetic heterogeneity.
Acknowledgments We want to thank all the students for participating in the questionnaire-based screening and the interviews. The help of Dr. Martina Grueter and Dr. Thomas Grueter, Münster, in performing a first check of part of the fourpage questionnaires is highly appreciated.

\section{References}

Ariel R, Sadeh M (1996) Congenital visual agnosia and prosopagnosia in a child: a case report. Cortex 32:221-240

Bamshad MJ, Wooding S, Watkins WS, Ostler CT, Batzer MA, Jorde LB (2003) Human population genetic structure and interference of group membership. Am J Hum Genet $72: 578-589$

Basu A, Mukherjee N, Roy S, Sengupta S, Banerjee S, Chakraborty M, Dey B, Roy M, Roy B, Bhattacharyya NP, Roychoudhury S, Majumder PP (2003) Ethnic India: a genomic view, with special reference to peopling and structure. Genome Res 13:2277-2290

Behrmann M, Avidan G (2005) Congenital prosopagnosia: faceblind from birth. Trends Cogn Sci 9:180-187

Bentin S, Deouell LY, Soroker N (1999) Selective visual streaming in face recognition: evidence from developmental prosopagnosia. Neuroreport 10:823-827

Bodamer J (1947) Die prosop-agnosie. Arch Psychiatr Nervenkr 179:6-53

De Gelder B, Rouw R (2000) Configural face processes in acquired and developmental prosopagnosia: evidence for two separate face systems? Neuroreport 11:3145-3150

De Haan EH (1999) A familial factor in the development of face recognition deficits. J Clin Exp Neuropsychol 21:312-315

De Haan EH, Campbell R (1991) A 15 year follow-up of a case of developmental prosopagnosia. Cortex 27:489-509

Dobel Ch, Bölte J, Aicher M, Schweinberger SR (2007) Prosopagnosia without apparent cause: Overview and diagnosis of six cases. Cortex (in press)

Duchaine BC (2000) Developmental prosopagnosia with normal configural processing. Neuroreport 11:79-83

Duchaine BC, Parker H, Nakayama K (2003) Normal recognition of emotion in a prosopagnosic. Perception 32:827-838

Galaburda AM, Duchaine BC (2003) Developmental disorders of vision. Neurol Clin 21:687-707

Grueter M (2004) Genetik der kongenitalen Prosopagnosie (Genetics of congenital prosopagnosia). Thesis (MD). Muenster University

Grueter M, Grueter T, Bell V, Halligan PW, Horst J, Sperling K, Laskowski W, Ellis HD, Kennerknecht I (2007) Hereditary prosopagnosia: first case series. Cortex (in press)

Hasson U, Avidan G, Deouell LY, Bentin S, Malach R (2003) Face-selective activation in a congenital prosopagnosic subject. J Cogn Neurosci 15:419-431

Jones RD, Tranel D (2001) Severe developmental prosopagnosia in a child with superior intellect. J Clin Exp Neuropsychol 3:265-273

Kennerknecht I, Grueter T, Welling B, Wentzek S, Horst J, Edwards S, Grueter M (2006) First report on the prevalence of non-syndromic hereditary prosopagnosia (HPA). Am J Med Genet Part A 140A:1617-1622

Kivisild T, Rootsi S, Metspalu M, Mastana S, Kaldma K, Parik J, Metspalu E, Adojaan M, Tolk HV, Stepanov V, Gölge M, Usanga E, Papiha SS, Cinnioğlu C, King R, Cavalli-Sforza L, Underhill PA, Villems R (2003) The genetic heritage of the earliest settlers persists both in Indian tribal and caste populations. Am J Hum Genet 72:313-332 
Kress T, Daum I (2003) Developmental prosopagnosia: a review. Behav Neurol 14:109-121

Kumar V, Reddy BM (2003) Status of Austro-Asiatic groups in the peopling of India: an exploratory study based on the available prehistoric, linguistic and biological evidences. J Biosci 4:507-522

McConachie HR (1976) Developmental prosopagnosia. A single case report. Cortex 12:76-82

Nunn JA, Postma P, Pearson R (2001) Developmental prosopagnosia: should it be taken at face value? Neurocase 7:1527

Qintana-Murci L, Krausz C, Zerjal T, Sayar H, Hammer MF, Mehdi SQ, Ayub Q, Qamar R, Mohyuddin A, Radhakrishna U, Jobling MA, Tyler-Smith C, McElreavey K (2001) Y-chromosome lineages trace diffusion of people and languages in southwestern Asia. Am J Hum Genet 68:537542
Saha A, Sharma S, Bhat A, Pandit A, Bamezai R (2005) Genetic affinity among five different population groups in India reflecting a Y-chromosome gene flow. Am J Hum Genet 50:49-51

Schwarzer G, Huber S, Grueter M, Grueter T, Groß C, Hipfel M, Kennerknecht I (2006) Gaze behavior in hereditary prosopagnosia. Psychol Res. DOI 10.1007/s00426-006-0068-

Temple CM (1992) Developmental memory impairment: faces and patterns. In: Campbell R (ed) Mental lives: case studies in cognition. Blackwell, Oxford, pp 199-215

Warrington EK (1984) Recognition memory test. NFER NELSON, Windsor

Young AW, Ellis HD (1989) Childhood prosopagnosia. Brain Cogn 9:16-47 